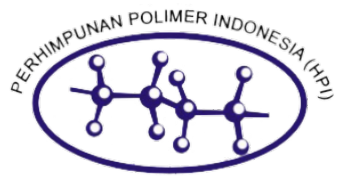

\title{
Pengaruh Iradiasi Gamma terhadap Perubahan Gugus Fungsi, Daya Serap Air dan Sterilitas Scaffold Kitosan/Kolagen
}

\begin{abstract}
Fajar Lukitowati ${ }^{\mathrm{a}}$, Rimma Patricia $^{\mathrm{b}}$, Noor Anis Kundari ${ }^{\mathrm{b}}$
Dalam rangka mendapatkan biomaterial sebagai media penyangga untuk mendukung proses pertumbuhan maupun perkembangan jaringan baru, telah dilakukan pembuatan scaffold kitosan/kolagen steril iradiasi gamma. Kitosan dan kolagen merupakan bahan alami yang biodegradabilitas dan biokompatibilitasnya tinggi serta banyak tersedia di alam. Iradiasi gamma dipilih sebagai cara sterilisasi tanpa merusak sifat fisika, kimia maupun biologi dari bahan. Penelitian ini bertujuan untuk mendapatkan scaffold kitosan/kolagen yang disterilkan dengan sinar gamma pada dosis steril (15 dan 25 kGy), dan mempelajari pengaruh iradiasi gamma terhadap perubahan gugus fungsi, daya serap air dan sterilitas scaffold kitosan/kolagen. Scaffold paduan kitosan/kolagen (50-50\% v/v) dibuat dengan cara freeze-drying dan diiradiasi gamma (dosis 0, 15 dan 25 kGy). Perubahan gugus fungsi diuji menggunakan Fourier Transform Infra Red (FTIR), daya serap air menggunakan timbangan analitik digital dan sterilitas scaffold dengan media fluid thioglicolate. Hasil pengukuran daya serap air dianalisis statistik dengan posthoc Tukey tingkat kepercayaan 0,05. Scaffold kitosan/kolagen menunjukkan penurunan intensitas pada gugus hidroksil dan amida setelah diiradiasi gamma. Dosis iradiasi yang diberikan tidak memberikan pengaruh bermakna pada daya serap air. Hasil berupa scaffold yang steril diberikan oleh scaffold yang diiradiasi dosis 15 dan 25 kGy. Kitosan/kolagen steril iradiasi dapat dipertimbangkan sebagai bahan biomaterial.
\end{abstract}

To obtain biomaterials as a supporting the growth process and the development of tissues, sterile chitosan/collagen scaffolds have been made by gamma irradiation. Chitosan and collagen are natural materials that have high biodegradability and biocompatibility and are widely available in nature. Gamma irradiation is chosen as a method of sterilization without damaging the physical, chemical and biological properties of the material. The aims of this present study are to obtain chitosan/collagen scaffolds which are sterilized with gamma at sterile doses (15 and $25 \mathrm{kGy}$ ), and analyze the effect of gamma-ray irradiation doses on their functional groups, water absorption and sterility. Chitosan/collagen scaffolds ( $50-50 \% \mathrm{v} / \mathrm{v}$ ) were prepared using the freeze-drying method and irradiated by gamma-rays (doses of 0,15 , and $25 \mathrm{kGy}$ ). Changes of functional groups were tested using Fourier Transform Infra Red (FTIR), water absorption using digital analytic scales, and scaffolds sterility with media fluid thioglycollate. The results of measurements of water absorption were analyzed statistically by Tukey's posthoc confidence level of 0.05 . Chitosan/collagen scaffolds show decreased intensity in hydroxyl and amide groups after gamma irradiation. The dose of irradiation given does not give a significant effect on water absorption. Sterile scaffold results were given by scaffold irradiated at 15 and $25 \mathrm{kGy}$. Irradiated chitosan/collagen scaffolds can be considered as a promising biomaterial.

28 December 2018

Published

28 June 2019

DOI: $10.37889 / \mathrm{mpi} .2019 .22 .1 .2$

Kata kunci: Daya serap air, iradiasi sinar gamma, kitosan, kolagen, perubahan gugus fungsi, scaffold, sterilitas.

\section{Pendahuluan}

Perbaikan, perawatan maupun pergantian jaringan sangat penting dilakukan untuk mengatasi degenerasi jaringan yang terjadi dalam tubuh manusia dapat disebabkan karena trauma, penyakit, penuaan maupun cacat bawaan. ${ }^{1}$ Scaffold merupakan biomaterial tiga dimensi berpori yang digunakan sebagai media penyangga sementara untuk mendukung proses pertumbuhan dan pengembangan jaringan baru. ${ }^{2}$ Menurut Gunatillake et al., ${ }^{3}$ scaffold harus bersifat

a. Pusat Aplikasi Isotop dan Radiasi (PAIR-BATAN), Jakarta

b. Sekolah Tinggi Teknologi Nuklir-BATAN, Yogyakarta

† Corresponding author: flukitowati@batan.go.id or ukilukitowati@gmail.com. fleksibel sesuai organ target, biocompatible, mendukung perkembangan seluler dan proliferasi sel serta kecepatan biodegradasinya dapat dikendalikan.

Selama beberapa dekade terakhir, polimer alam banyak digunakan dalam aplikasi dalam bidang biomedis. Polimer alam yang digunakan dapat berupa polimer tunggal maupun campuran. Polimer campuran mulai banyak diteliti karena memadukan sifatsifat menguntungkan dari beberapa polimer tunggal. Campuran polimer seperti dari kitosan dan kolagen (kitosan/kolagen) banyak digunakan sebagai scaffold karena sifat-sifat menguntungkan dari kedua bahan tersebut.

Kitosan merupakan polisakarida hasil deasetilasi dari kitin dan banyak ditemui pada cangkang hewan kelas Crustacea. Kitosan memiliki gugus aliphatic $(-\mathrm{CH})$, eter $(-\mathrm{C}-\mathrm{O}-\mathrm{C})$, hidroksil $(-\mathrm{OH})$ yang bersifat hidrofilik ${ }^{4}$ serta amida (-NH) yang bertindak sebagai kation dan pengubah muatan (ion exchanger)..$^{5-6}$ Serupa dengan beberapa 
polimer kationik lainnya, kitosan dapat merusak membran terluar bakteri yang mengandung anion yang selanjutnya dapat menghambat pertumbuhannya. Namun demikian, kekurangan dari kitosan adalah sifatnya yang kurang lentur sehingga mengakibatkan keterbatasan dalam pengaplikasiannya.

Kolagen dapat ditemukan pada kulit hewan mamalia atau cumicumi, sisik ikan, ${ }^{7-9}$ tendon sapi. ${ }^{10-12}$ Dari tendon bovine dapat diekstrak kolagen sebanyak $85 \% .8,11$ Kolagen tersusun dari tiga rantai polipeptida (yaitu glisin, prolin dan hidroksiprolin) yang tersusun dalam rantai triple helix. Gugus hidrofilik yang terkandung dalam glisin, prolin dan hidroksiprolin adalah karboksil (- $\mathrm{COOH})$, amida (-NH) dan hidroksil (-OH). kolagen membentuk suatu jaringan makromolekul yang diketahui mampu meningkatkan kekuatan struktural dan keelastisitasan suatu bahan.

Bahan kesehatan terutama bahan implan yang langsung berkontak dengan cairan tubuh harus bersifat steril. Salah satu metode untuk meningkatkan sterilitas suatu bahan adalah dengan iradiasi gamma. Dibanding metode yang lain, metode ini lebih murah, efektif dan aman karena tidak meninggalkan residu pada bahan. Menurut ISO $11137,{ }^{13}$ dosis iradiasi gamma yang diberikan untuk sterilisasi bahan kesehatan adalah 15 atau 25 kGy. Namun demikian, iradiasi mengakibatkan perubahan sifat fisika, kimia dan biologi pada bahan.

Pengujian kekuatan mekanik dan perubahan gugus fungsi membran kitosan/kolagen iradiasi gamma telah dilakukan oleh Indrani et al. ${ }^{4}$ Sionkowska et al. ${ }^{14}$ melakukan pengujian pengaruh iradiasi gamma terhadap sifat thermal dan mekanik pada kolagen tendon sapi. Pada penelitian sebelumnya Lukitowati dan Indrani ${ }^{15}$ telah melakukan analisa mengenai daya serap air pada membran kitosan/kolagen iradiasi gamma, sedangkan pengaruh iradiasi sinar gamma terhadap daya antibakteri kitosan telah diteliti oleh Tahtat el al. ${ }^{16}$ Namun demikian belum ada penelitian mengenai pengaruh iradiasi gamma terhadap sifat fisiko-kimia scaffold kitosan/kolagen. Oleh karena itu, dalam penelitian ini dilakukan pembuatan scaffold kitosan/kolagen yang disterilkan dengan sinar gamma pada dosis steril (15 dan $25 \mathrm{kGy}$ ), dan mempelajari pengaruh iradiasi gamma terhadap perubahan gugus fungsi, daya serap air dan sterilitas scaffold kitosan/kolagen.

\section{Metode Percobaan}

\section{Alat dan Bahan}

Bahan utama yang digunakan dalam penelitian ini antara lain adalah kitosan medical grade dengan derajat deasetilasi $90 \%$ dan berat molekul 170 kDa yang diperoleh dari PT. Biotech Surindo (Cirebon), tendon sapi yang telah tersedia di laboratorium Bank Jaringan PAIRBATAN. Reagen yang digunakan adalah asam asetat, natrium klorida ( $\mathrm{NaCl})$, buffer fosfat, natrium hidroksida $(\mathrm{NaOH})$ buatan Merck dan media fluid thioglycolate buatan Difco.

\section{Cara Kerja}

\section{Pembuatan scaffold kitosan/kolagen}

Pembuatan larutan kitosan mengikuti prosedur dari Ramasamy and Shanmugam. ${ }^{7}$ Pembuatan larutan kolagen dalam asam asetat $0,7 \mathrm{M}$ sesuai dengan metode yang dilakukan oleh Fernandes. ${ }^{17}$ Selanjutnya scaffold kitosan/kolagen dibuat mengikuti prosedur dari Uriarte-Montoya et al. ${ }^{8}$ Larutan kitosan dan kolagen dicampur dengan rasio 50:50 (v/v) kemudian diaduk menggunakan magnetic stirrer dengan kecepatan $700 \mathrm{rpm}$ pada suhu kamar selama $12 \mathrm{jam}$. Selanjutnya campuran ini dicetak dengan cetakan berukuran $7 \times 7 \mathrm{~cm}^{2}$, dibekukan pada suhu $-80^{\circ} \mathrm{C}$ selama 24 jam dan dikeringkan dengan metode liofilisasi (freeze-drying) selama \pm 72 jam.

\section{Iradiasi scaffold}

Scaffold yang telah kering dikemas dalam plastik polypropylene (PP) untuk selanjutnya disterilkan menggunakan radiasi sinar gamma dengan dosis 15 dan 25 kGy (dosis 0 kGy digunakan sebagai kontrol).

\section{Pengujian gugus fungsi}

Pengujian gugus fungsi scaffold menggunakan Fourier Transform Infra-Red (FTIR) Spektrofotometer UV-mini 1240 (Shimadzu). Sampel kering dicampur dengan kalium bromide $(\mathrm{KBr})$ dengan perbandingan 1:200 dan dimasukkan ke dalam tempat sampel (pan) untuk selanjutnya diukur spektrumnya pada bilangan gelombang $4000 \mathrm{~cm}^{-1}$ sampai $400 \mathrm{~cm}^{-1}$.

\section{Pengujian daya serap air}

Pengujian daya serap air dilakukan sesuai ASTM F215018 dan mengikuti prosedur pada penelitian Sultana and Khan. ${ }^{19}$ Spesimen scaffold iradiasi berukuran $1 \times 1 \mathrm{~cm}$ dikeringkan dengan oven pada suhu $37^{\circ} \mathrm{C}$ selama 48 jam. Selanjutnya spesimen ditimbang dengan timbangan digital analitik dan dicatat beratnya. Masing-masing spesimen kemudian direndam pada akuades $\mathrm{pH} 7,4$ dengan interval waktu 0,5; 1 dan 24 jam. Setelah mencapai interval waktu tersebut, spesimen dikeluarkan dari akuades, dikeringkan permukaannya dengan kertas saring dan kemudian ditimbang kembali untuk mengetahui perubahan beratnya. Persentase daya serap air diukur dengan persamaan:

Persentase daya serap air $(\%)=\frac{w_{0}-w_{1}}{w_{1}} \times 100 \%$

di mana $W_{0}$ adalah berat scaffold kitosan/kolagen sebelum perendaman, $W_{1}$ adalah berat scaffold kitosan/kolagen setelah perendaman sesuai interval waktu.

Hasil pengukuran selanjutnya dianalisis secara statistik dengan program Statistical Package for the Social Science versi 16.0 (SPSS v. 16.0) dengan menggunakan sistem analisis One Way Analysis of Variance (One Way ANOVA) menggunakan posthoc Tukey tingkat kepercayaan 0,05.

\section{Pengujian sterilitas}

Media fluid thioglicolate digunakan untuk pengujian sterilitas sesuai dengan metode Test Sterility dari World Health Organization. ${ }^{20}$ Masing-masing spesimen scaffold dimasukkan dalam media fluid thioglicolate secara aseptis dan diinkubasi pada suhu $37^{\circ} \mathrm{C}$. ada tidaknya perubahan kekeruhan pada media fluid thioglicolate diamati dari hari ke-0 sampai dengan hari ke-7.

\section{Hasil dan Pembahasan}

Ada tidaknya perubahan gugus fungsi scaffold kitosan/kolagen yang diiradiasi gamma pada dosis 0,15 dan 25 kGy ditampilkan pada 
Gambar 1. Sumbu X menunjukkan bilangan gelombang (dalam $\mathrm{cm}$ $\left.{ }^{1}\right)$ dan sumbu $Y$ menunjukkan transmittan (dalam \%). Dari Gambar 1 , terlihat bahwa puncak dari gugus penyusun scaffold kitosan/kolagen merupakan gabungan antara puncak dari gugus kitosan (C-O$\mathrm{C},-\mathrm{NH},-\mathrm{CH}$ dan $-\mathrm{OH}$ ) dan kolagen (amida I, amida II dan amida III). Pengamatan hasil spektrum FTIR secara visual menunjukkan bahwa dengan pemberian iradiasi sinar gamma menimbulkan perubahan intensitas puncak akibat pemberian iradiasi gamma. Scaffold kitosan/kolagen yang diiradiasi dengan dosis $15 \mathrm{kGy}$ memiliki intensitas puncak gugus - $\mathrm{OH}$ yang lebih rendah dibanding scaffold kitosan/kolagen tanpa iradiasi. Hal yang sama juga nampak pada scaffold kitosan/kolagen yang diberi dosis iradiasi sebesar 25 kGy, yang mana menunjukkan intensitas yang lebih rendah lagi.

Daya serap air scaffold tanpa dan dengan iradiasi gamma (15 dan 25 kGy) ditampilkan pada Gambar 2. Daya serap air scaffold berkisar dari 595 sampai 903\%. Namun demikian, hasil analisa statistik menunjukkan tidak ada beda signifikan antara perlakuan. Scaffold menunjukkan nilai daya serap yang besar pada setengah jam pertama dan terus meningkat seiring waktu perendamanannya. Seperti nampak pada hasil, pada waktu perendaman yang sama daya serap scaffold yang diiradiasi gamma dosis 15 kGy me-miliki nilai yang tertinggi yaitu sebesar, diikuti oleh scaffold yang diiradiasi pada dosis $25 \mathrm{kGy}$ dan scaffold tanpa iradiasi secara berurutan. Scaffold kitosan/kolagen tanpa iradiasi pada perendaman 30 menit pertama memiliki nilai daya serap air sebesar $595 \pm 19,90 \%$, yang mana nilai ini mendekati nilai daya serap air pada scaffold kitosan/kolagen/poly(N,N-diethylacrylamide) yang di-lakukan oleh Barroso et al. ${ }^{22}$ yaitu sebesar $500 \%$. Dengan penambahan dosis iradiasi sebesar 15 kGy terjadi peningkatan nilai daya serap air menjadi $837,63 \pm 41,32 \%$. Hal ini kemungkinan disebabkan karena iradiasi menyebabkan putusnya ikatan-ikatan rangkap dari kitosan menjadi ikatan polar yang menjadi lebih banyak untuk berikatan dengan gugus polar dari air. Namun untuk scaffold yang diiradiasi dengan dosis 25 kGy terlihat bahwa nilai daya serap airnya lebih rendah dibanding dosis 15 kGy. Kemungkinan yang menyebabkan hal ini adalah turunnya intensitas dari dari gugus-gugus fungsional yang bersifat polar.

Pengujian sterilitas scaffold dilakukan menggunakan media fluid thioglicolate. Pengujian ini bertujuan untuk memastikan scaffold yang ditujukan bahan implan yang langsung berkontak dengan cairan tubuh bersifat aman dan tidak membawa kontaminasi dari luar. Media fluid thioglicolate merupakan media yang mampu mendeteksi adanya bakteri baik aerob maupun anaerob. Ada tidaknya pertumbuhan bakteri ditunjukkan dengan perubahan kekeruhan media fluid thioglicolate. Hasil uji sterilitas scaffold tanpa dan dengan iradiasi sinar gamma (15 dan $25 \mathrm{kGy}$ ) ditampilkan pada Tabel 1.

Dari Tabel 1 terlihat perbedaan sterilitas untuk scaffold akibat pengaruh pemberian iradiasi sinar gamma. Media fluid thioglicolate untuk scaffold tanpa iradiasi sampai dengan hari ke-3 masih menunjukkan media yang bening, hal ini berarti scaffold masih steril dan tidak menunjukkan adanya pertumbuhan bakteri. Setelah hari ke-4, media fluid thioglicolate untuk scaffold tanpa iradiasi menunjukkan kekeruhan yang menandakan adanya pertumbuhan bakteri. Hal ini mungkin disebabkan karena pada scaffold tanpa iradiasi terdapat bakteri yang berkembang karena asupan energi dari media fluid thioglicolate. Lain halnya untuk scaffold yang diberikan dosis iradiasi sinar gamma 15 dan $25 \mathrm{kGy}$, sampai dengan hari ke-7 pengamatan tidak ditemukan perubahan pada media fluid thioglicolate dan media tetap bening. Hal ini berarti iradiasi yang diberikan pada masingmasing scaffold mampu mengeliminasi adanya bakteri sehingga tidak menimbulkan kontaminasi. Iradiasi gamma mengakibatkan efek ionisasi pada mikroorganisme secara molekuler. Efek ini mengenai ke penyusun materi genetik terutama DNA yang mengakibatkan kerusakan. Kerusakan pada DNA menyebabkan gangguan pada sistem metabolisme bakteri yang selanjutnya mengakibatkan kematian bakteri.

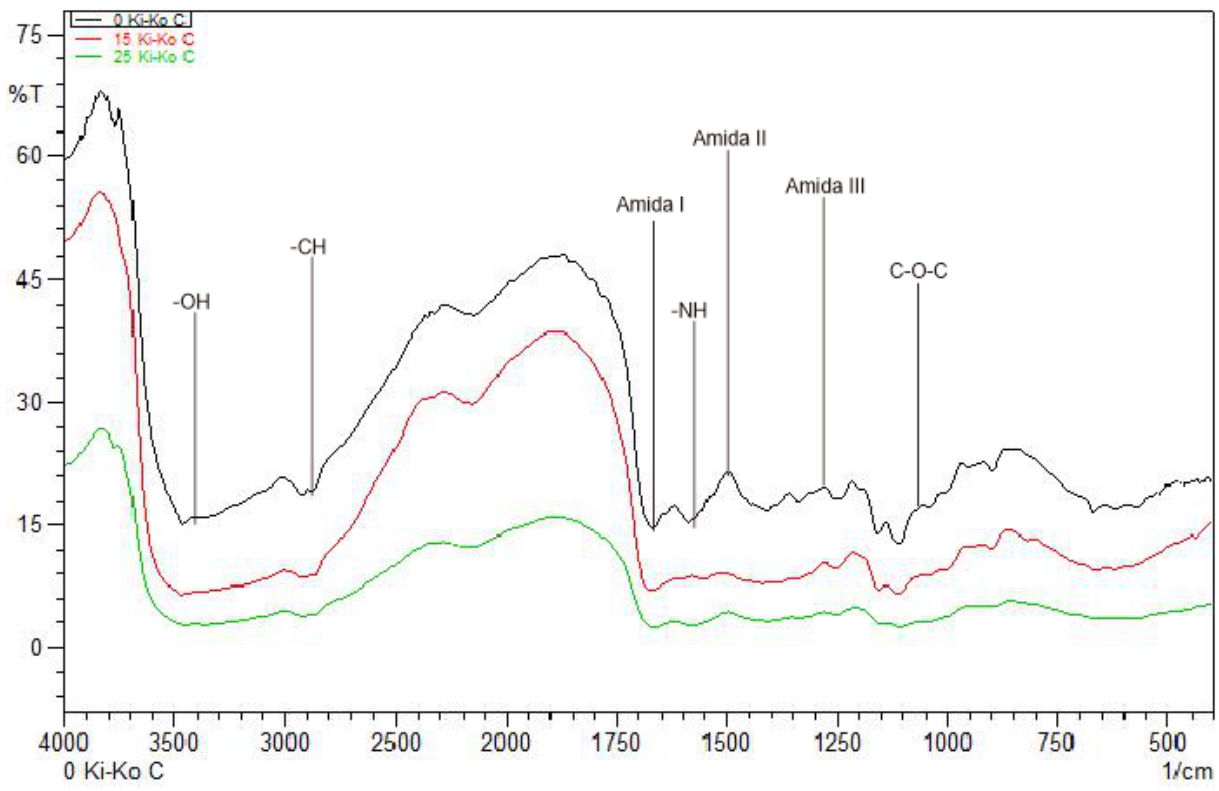

Gambar 1. Spektroskopi FTIR scaffold kitosan/kolagen iradiasi gamma dosis 0, 15 dan 25 kGy. 


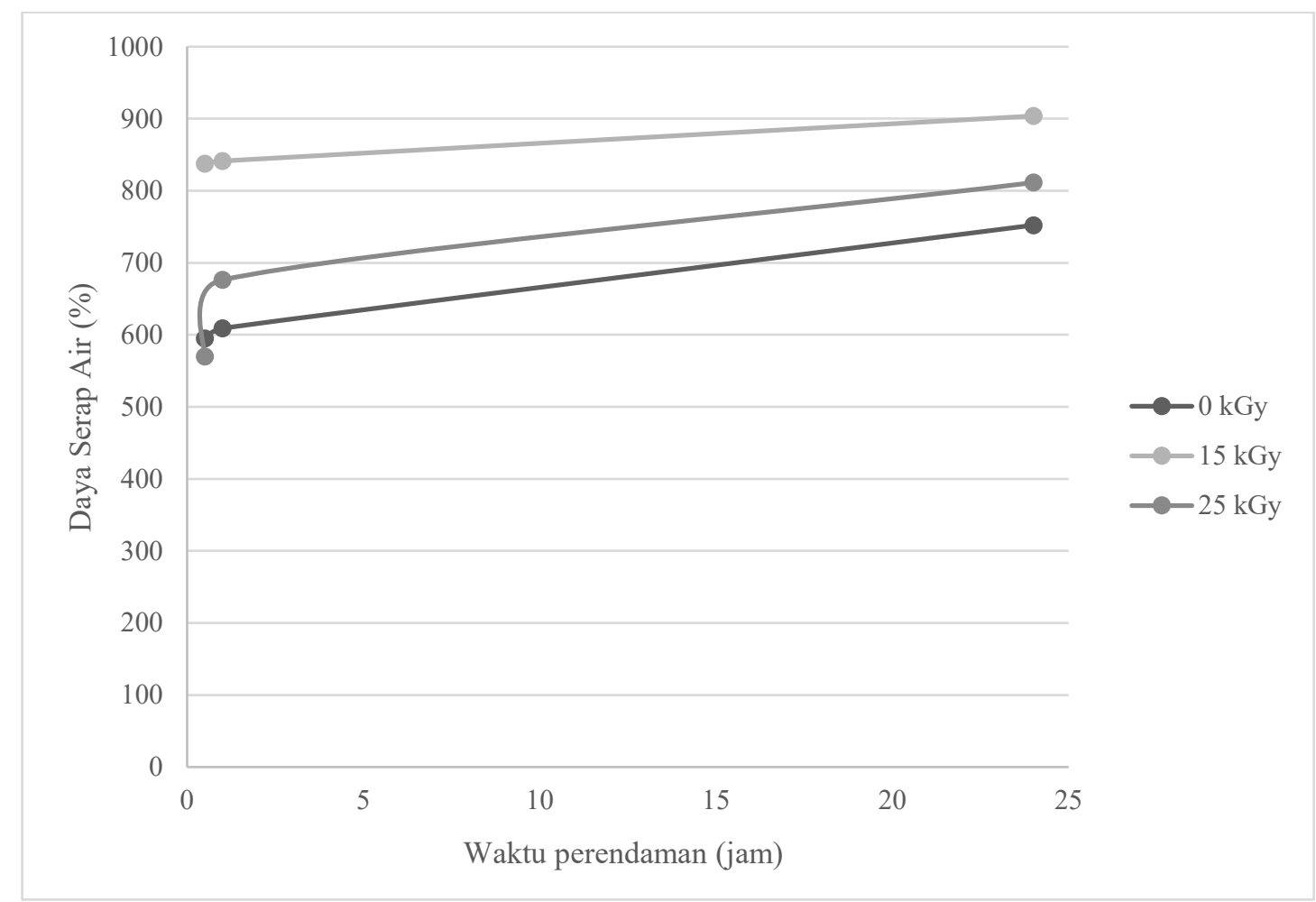

Gambar 2. Daya serap air scaffold kitosan/kolagen iradiasi gamma dosis 0, 15 dan 25 kGy.

Tabel 1. Uji sterilitas scaffold kitosan/kolagen dengan iradiasi gamma dosis 0,15 dan $25 \mathrm{kGy}$

\begin{tabular}{cccc}
\hline & & \multicolumn{2}{c}{ Hasil } \\
\cline { 2 - 4 } Hari ke- & $\begin{array}{c}\text { Dosis iradiasi } \\
\text { sinar gamma } \\
\mathbf{0} \text { kGy }\end{array}$ & $\begin{array}{c}\text { Dosis iradiasi } \\
\text { sinar gamma } \\
15 \text { kGy }\end{array}$ & $\begin{array}{c}\text { Dosis iradiasi } \\
\text { sinar gamma } \\
\mathbf{2 5} \text { kGy }\end{array}$ \\
\hline 0 & - & - & - \\
\hline 1 & - & - & - \\
\hline 2 & - & - & - \\
\hline 3 & - & - & - \\
\hline 4 & + & - & - \\
\hline 5 & + & - & - \\
\hline 6 & + & - & - \\
\hline 7 & + &
\end{tabular}

\section{Kesimpulan}

Dosis iradiasi gamma yang diberikan tidak memberikan pengaruh bermakna terhadap daya serap air namun menyebabkan penurunan intensitas pada gugus hidroksil dan amida serta perubahan sterilitas dari scaffold kitosan/kolagen. Dengan demikian scaffold kitosan/kolagen yang diiradiasi gamma dapat dipertimbangkan sebagai bahan biomaterial.

\section{Ucapan Terima Kasih}

Penulis mengucapkan terimakasih pada Drs. Erizal atas diskusi dan masukan yang diberikan serta pada M. Yasin atas bantuan untuk mengiradiasi scaffold kitosan/kolagen ini.

\section{Referensi}

1 F.J. O'Brien, Biomaterials \& scaffolds for tissue engineering, Mater. Today, 2011, 14(3), 88-95.

2 M.R. Aufan, A.H. Daulay, D. Indriani dan A. Nuruddin, Sintesis Scaffold Alginat-Kitosan-Karbonat Apatit sebagai Bone Graft Menggunakan Metode, J. Biofisika, 2012, 8(1), 16-24.

3 P.A. Gunatillake, R. Adhikari dan N. Gadegaard, Biodegradable synthetic polymers for tissue engineering, Eur. Cells Mater., 2003, 5, 1-16.

4 D.J. Indrani, F. Lukitowati dan Y. Yulizar, Preparation of Chitosan/Collagen Blend Membranes for Wound Dressing: A Study on FTIR Spectroscopy and Mechanical Properties, IOP Conf. Ser. Mater. Sci. Eng., 2017, 202(1). 
5 S.K. Nitta dan K. Numata, Biopolymer-based nanoparticles for drug/gene delivery and tissue engineering, Int. J. Mol. Sci., 2013 14(1), 1629-1654.

6 Z. Chen, X. Mo, C. He dan H. Wang, Intermolecular interactions in electrospun collagen-chitosan complex nanofibers, Carbohydr. Polym., 2008, 72(3), 410-418.

7 P. Ramasamy dan A. Shanmugam, International Journal of Biological Macromolecules Characterization and wound healing property of collagen-chitosan film from Sepia kobiensis (Hoyle, 1885), Int. J. Biol. Macromol.,2015, 74, 93-102.

8 M.H. Uriarte-Montoya et al., Jumbo squid (Dosidicus gigas) mantle collagen: extraction, characterization, and potential application in the preparation of chitosan-collagen biofilms, Bioresour. Technol., 2010, 101(11), 4212-9.

9 C.Y. Huang, J.M. Kuo, S.J. Wu dan H.T. Tsai, Isolation and characterization of fish scale collagen from tilapia (Oreochromis sp.) by a novel extrusion-hydro-extraction process, Food Chem., 2016, 190, 997-1006.

10 D. Rushadi dan F. A. Rantam, Regenerasi pada Massive Bone Defect dengan Bovine Hydroxyapatite sebagai Scaffold Mesenchymal Stem Cell (Regeneration of Massive Bone Defect with Bovine Hydroxyapatite as Scaffold of Mesenchymal Stem Cells), 2011, 13(3), 179-195.

11 S. Techatanawat, R. Surarit, T. Suddhasthira dan S. O. P. Khovidhunkit, Type I collagen extracted from rat-tail and bovine Achilles tendon for dental application: A comparative study, Asian Biomed., 2011, 5(6), 787-798.
12 K.S. Silvipriya, K. Krishna Kumar, A.R. Bhat, B.D. Kumar, A. John dan P. Lakshmanan, Collagen: Animal sources and biomedical application, J. Appl. Pharm. Sci., 2015, 5(3), 123-127.

13 A.N. Standard, American National Standard Ansi/Iso, 2008, 2010.

14 A. Sionkowska, M. Wisniewski, J. Skopinska dan G.F. Poggi, Therma and mechanical properties of UV irradiated collagen / chitosan thin films, 2006, 91, 3026-3032.

15 F. Lukitowati dan D. Joesiana, Water Absorption of Chitosan, Collagen, and Chitosan/Collagen Blend Membranes Exposed to Gamma-Ray Irradiation, 2018, 14(1), 57-66.

16 D. Tahtat, M. Mahlous dan S. Benamer, Influence of some factors affecting antibacterial activity of PVA/Chitosan based hydrogels synthesized by gamma irradiation, 2011, 2505-2512.

17 L.L. Fernandes, C.X. Resende, D.S. Tavares, G.A. Soares, L.O. Castro dan J.M. Granjeiro, Cytocompatibility of chitosan and collagen-chitosan scaffolds for tissue engineering, Polímeros, 2011, 21(1), 1-6.

18 A. Ratcliffe, Tissue Engineered Medical Products (TEMPS), 2004.

19 N. Sultana dan T.H. Khan, Water absorption and diffusion characteristics of nanohydroxyapatite $(\mathrm{nHA})$ and poly(hydroxybutyrateco-hydroxyvalerate-) based composite tissue engineering scaffolds and nonporous thin films, J. Nanomater., 2013, 2013(May).

20 P. Against dan M. Contamination, 3.2 Test for Sterility, 2012, March, 1-5. 